\title{
Chinese Cyber Citizens' Perception on the Chinese Dream
}

\author{
Rui-Rui WU \\ School of Humanities, Economics and Law, Northwestern Polytechnical University, Xi'an \\ wuruirui918@163.com
}

Keywords: Chinese Dream, Cyber Citizens, Perception and understanding.

\begin{abstract}
Network survey showed that there were some problems in the Chinese cyber citizen's understanding on the Chinese Dream. Specifically, examples can be seen in inaccurate cognition and lack of confidence. In order to fulfill the Chinese Dream, the media and schools should further strengthen its effects on publicity and education. Moreover, the government needs to carry on its deepening reform in all rounds, to achieve a rational resource allocation, to ensure social fairness and justice. Meanwhile, the broad masses of the people must take practical action to achieve the Chinese Dream.
\end{abstract}

\section{Introduction}

General Secretary Jin-Ping XI put forward Chinese Dream when he was visiting the Road to Revival exhibition after the 18th congress of Communist Party of China. At the closing meeting of the first session of the 12th National People's Congress, he pointed out the Chinese Dream is to achieve great rejuvenation for the Chinese nation in the perspective of national prosperity, social harmony and happiness of the people. ${ }^{[1]} \mathrm{He}$ extended the rich connotation of the Chinese Dream again when he was taking a written interview with the Wall Street journal on September 22, 2015. What's more, he mentioned the close relation between the Chinese Dream and American Dream. No doubt, his profound speech caused widespread concern in academic circles.

Currently, the articles about Chinese Dream mainly focused on its ideological origins, theoretical connotation and realization way. However, the essay on the peoples' perception of the Chinese Dream is seldom concerned. This article is aimed at exploring the national perception of the Chinese Dream through analyzing the network survey data. The author hopes it will make some insights of the ideal education in the future.

\section{Chinese Cyber Citizens' Perception of the Chinese Dream}

When the Chinese Dream became a hot topic in China, in order to fully understand the public's cognition and demand on it, CNTV made an online survey on "Chinese Dream and I". At the same time, Phoenix net and Tencent Guangdong net respectively conducted a survey on cyber citizens' perception on the Chinese Dream. There were 3621, 9890, 8776 cyber citizens taking part in the CNTV, Phoenix net, and Tencent Guangdong net survey. Due to the wide audiences, strong subjective influence, different styles of questionnaire design from these sites, the results are credible. This paper will be based on the data from them to explore current Internet users' perception on this issue in China.

According to the survey data, the current Chinese cyber citizens' understanding on the Chinese Dream has the following features:

Firstly, most Internet users are more likely to understand the Chinese Dream from national and social level. 
Data sources: "Chinese Dream and I", http://app1.vote.cntv.cn/viewResult.jsp?voteId=10447;

"What is the Chinese Dream in your heart", http://survey.ifeng.com/news/3737.html;"The questionnaire survey on the Chinese Dream", http://gd.qq.com/zt2013/zhongguomeng/index.htm.

\begin{tabular}{|c|c|c|c|}
\hline \multicolumn{4}{|c|}{ What do you think of the Chinese Dream? } \\
\hline \multirow{5}{*}{ CNTV } & Option & Vote & Percentage \\
\hline & The realization of the great rejuvenation of the Chinese nation & 1931 & $35.88 \%$ \\
\hline & The realization of personal dream & 970 & $18.02 \%$ \\
\hline & upright cadres, well-arranged government and upright politics & 1443 & $26.81 \%$ \\
\hline & As long as the hard work can get success & 1038 & $19.29 \%$ \\
\hline \multicolumn{4}{|c|}{ What is the Chinese Dream in your heart? } \\
\hline \multirow{5}{*}{$\begin{array}{l}\text { Phoenix } \\
\text { Net }\end{array}$} & Option & Vote & Percentage \\
\hline & National prosperity and rejuvenation & 2071 & $21.33 \%$ \\
\hline & $\begin{array}{l}\text { The realization of social fairness, justice, a mature market } \\
\text { environment and sound legal system }\end{array}$ & 6334 & $65.25 \%$ \\
\hline & Wealthy life & 1066 & $10.98 \%$ \\
\hline & Others & 237 & $2.44 \%$ \\
\hline \multicolumn{4}{|c|}{ When it comes to the Chinese Dream, what will you think of it? } \\
\hline \multirow{7}{*}{$\begin{array}{l}\text { Tencent } \\
\text { Guangd } \\
\text { ong Net }\end{array}$} & Option & Vote & Percentage \\
\hline & National prosperity, rejuvenation, and the people's well-being & 4248 & $49.36 \%$ \\
\hline & The realization of harmony between society, people and environment & 2124 & $24.68 \%$ \\
\hline & The happiness of the state and its people & 403 & $4.68 \%$ \\
\hline & The realization of communism & 333 & $3.87 \%$ \\
\hline & Rapid and stable economic development & 275 & $3.20 \%$ \\
\hline & Others & 1224 & $14.22 \%$ \\
\hline
\end{tabular}

Table 1 showed that $35.88 \%, 21.33 \%$, 49.36\% respondents from CNTV, Phoenix net, Tencent Guangdong net regarded Chinese Dream as the concept of national prosperity and rejuvenation. It is easy to find that the ratio of Tencent Guangdong net is higher than the other two websites. This is largely due to the design of the questionnaire from various perspective. Indeed, CNTV, Phoenix net focused on national, social and individual level to investigate internet users' perception on the Chinese Dream. There is no inclusive relationship between options. But Tencent Guangdong net intended to probe into whether people's understanding of the Chinese Dream is comprehensive and accurate. Compared with other options from this particular questionnaire, the item "National prosperity, rejuvenation, and the people's well-being" is inclusive and priority, so the ratio is higher.

Nearly 2/3 of the Phoenix net participants believed that Chinese Dream would achieve social fairness and justice to create a mature market environment and sound legal system. $26.81 \% \mathrm{CNTV}$ survey participants paid attention to the reform of political system, regarding Chinese Dream as the upright cadres, well-arranged government and upright politics. $19.29 \%$ respondents regarded Chinese Dream as social justice, thinking it means "As long as the hard work can get success". Nearly 1/4 of the Tencent Guangdong net participants believed that Chinese Dream would refer to the realization of harmony between society, people and environment, etc. It is not difficult to see that the Internet users are very concerned about the objective of Chinese Dream from social sphere.

It showed that Internet users realized the overall goal of Chinese Dream would be the achievement of the national prosperity and rejuvenation. At the same time, they also noted that current Chinese socialist market economic system was not mature, the political system and the legal system were not perfect. Therefore, further deepening the reform of economic and political system, strengthening social construction, building a fair and righteous platform, are the inevitable requirements. 
Secondly, when it comes to the relationship between Chinese Dream and personal dream, most Internet users believed that the two related closely. But there were different understandings in the specific relationship.

Most participants took the view that Chinese Dream would be closely related to personal dream. But they were divided on the specific relations of the two. About one-third of survey participants from CNTV, Phoenix net, and Tencent Guangdong net regarded Chinese Dream as the sum of all the Chinese people's dreams. And $23.86 \%$ CNTV participants thought it would be the intersection of all personal dreams. The former means that every personal dream is an integral part of the Chinese Dream. The latter means that only people's common ideal can be called the Chinese Dream. The both agree that every personal dream is part of the Chinese Dream. Unlike the first two, 32.4\% Phoenix net survey participants and $4.34 \%$ Tencent Guangdong net participants regarded personal dream as the Chinese Dream.

From the questionnaire we can infer the ultimate aim of Internet users, too. $23.40 \% \mathrm{CNTV}$ participants believed that sharing the achievements of Chinese dream would be the realization of personal dreams. 20.54\% Phoenix net participants and $19.31 \%$ Tencent Guangdong net participants took the view that personal dreams could only be realized when the Chinese Dream had been realized. These participants regarded national dream as their ultimate aim. This shows that most cyber citizens agree that the Chinese Dream is a combination of personal dreams and national dreams, and the realization of personal dream is inseparable from the support of nation dream. In contrast, 20.23\% CNTV participants who thought Chinese Dream would be a stage for the realization of personal dream, and $32.4 \%$ Phoenix net participants and $4.34 \%$ Tencent Guangdong net participants who regarded personal dream as the Chinese Dream, paid more attention to their personal dreams. This proves that the Chinese Dream is essentially the dream of people, and each Chinese is a participant, builder, and sharer.

In addition, it must to be noted that $35.82 \%$ Tencent Guangdong net participants and $8 \%$ Phoenix net participants thought there was no relationship between the Chinese Dream and personal dream. Schools and government should pay attention to this situation, identify the cause, intensify propaganda and education, and strengthen the public responsibility to achieve the Chinese Dream.

\section{The Psychological Expectations about the Realization of Chinese Dream}

Tencent Guangdong net also surveyed cyber citizen's psychological expectations about the realization of Chinese Dream. The results showed that only $5.87 \%$ of the participants believed that it would be able to achieve. $32.58 \%$ said it would be impossible to come true. $53.82 \%$ thought the Chinese Dream could be realized in the case of some obstacles to overcome. Another $7.73 \%$ participants did not to say yes or no. The good news is that nearly sixty percent of the participants have confidence in the realization of Chinese Dream. Worrying is that nearly one-third of the participants were pessimistic and despairing.

Therefore, on the one hand, the government needs to strengthen the propaganda and education on Chinese Dream, help more citizens, especially young people, to set up the common ideal of the great rejuvenation of the Chinese nation. On the other hand, it should be clearly recognized that the realization of Chinese Dream still has a long way to go. The society and the government need to understand the public appeal, find the reasons for the lack of confidence, and then remedy and resolve contradictions, firm citizen's confidence on the realization of the Chinese Dream.

In Internet users' view, what factors hinder the realization of the Chinese Dream?

Firstly, social injustice is the biggest barrier to the implementation of the Chinese Dream.

$79.99 \%$, 25.59\%, 80.79\% participants from CNTV, Phoenix net, Tencent Guangdong net regarded injustice as the biggest obstacle. One of the prominent features of social injustice is unfair distribution. In recent years, the income gap of residents in our country is becoming larger and larger. According to the information published by the National Bureau of statistics, China's Gini 
coefficient is over 0.4 (international cordon) for 11 consecutive years. ${ }^{[2]}$ This situation makes people more look forward to the income distribution reform. $69.43 \%$ CNTV survey participants thought that the government's most urgent task would be to realize the rational allocation of resources, and break through the barriers of interest and build social justice.

At the same time, netizens also noticed that the lack of equal competition opportunity and platform is the main obstacle to self-realization. 34.19\%, 34.3\% participants from CNTV, Tencent Guangdong net regarded competition of family background as the biggest barrier to the achievement of a personal dream. In recent years, the highly focused events such as "my father is $\mathrm{Li}$ gang" indicate that the public are very dissatisfied with the competition of family background. As the World Bank's "2006 World Development Report: equity and development" points out, from an equal point of view, the equality of opportunity is more important than the results of the distribution. [3] Because the equality of starting and opportunity is the prerequisite and basis for the result equality. For the realization of Chinese Dream, the social injustice will seriously affect the individual's enthusiasm, thus inevitably hinder it.

Secondly, corruption is the main factor that affects the realization of the Chinese Dream.

$57.37 \%$ of respondents from Tencent Guangdong net took this view. $22.19 \%$ CNTV survey participants called on the government to improve the anti-corruption system. Transparency International ranked China 80 out of 177 countries on their 2013 global corruption perception index. [4] These data showed that the public had a subjective perception of the current serious corruption problem in our country.

That is the case. Researchers who have made statistical analysis on publicly reported 2802 corruption cases found that the amount of money involved in these cases had a clear upward trend, and the degree of corruption continues to deepen. [5]

Because corruption had severely weakened the administrative ability of the government, undermined the social order and morals, hindered the realization of Chinese Dream, and shaken the foundation of the ruling party, so in recent years, China has stepped up anti-corruption efforts. According to incomplete statistics, from the 18th CPC National Congress closing to the end of June 2015, at least investigated 76 provincial and ministerial officials, and retrieved the economic loss of 38.7 billion Yuan. The number and rank of officials involved is shocking.

In general, netizens deemed that domestic problems, especially injustice and corruption, would be the fundamental factors hindering the Chinese Dream.

\section{The Necessary Condition to Realize the Chinese Dream}

General Secretary Jin-Ping XI advocated the Chinese Dream. He hoped that the people across the country could set up the common ideal, and work together for the great rejuvenation of the Chinese nation. But the above analysis showed that there were some problems in the Chinese cyber citizen's understanding of the Chinese Dream, such as cognitive inaccurate, lack of confidence and so on. The realization of Chinese Dream still has a long way to go. It urgently needs that the relevant departments cooperate effectively, improve the citizen's understanding of the Chinese Dream, and gather the power of the dream. Specifically, it includes the following aspects:

First, Schools and the media should strengthen the propaganda and education of the Chinese Dream.

"Understanding" and "belief" are the precondition of the "action". In order to gather the power of the dream, you must make people understand and agree with the Chinese Dream first. But we found that some Internet users still separated the Chinese Dream with personal dreams, and failed to recognize that the Chinese Dream would be the organic whole of personal dreams and the nation dream. They didn't know that "only in the full realization of the collective dream can the realization of a single subject, specific dream, get the most fundamental guarantee". ${ }^{[6]}$ Therefore, schools and the media should strengthen the propaganda and education, and let people understand the Chinese 
Dream is an organic unity of the collective dream and personal dream, enhance their recognition of the Chinese dream, and gather the strong power of the dream.

Youth is the future of the nation. China should take teenagers as the center of the Chinese Dream Education, and establish the Four in One Teaching Mode which includes school education, family education, social education and network education to enhance their recognition of the Chinese Dream and help them set up the common ideal. What needs to be pointed out is that social practice is significant in the Chinese Dream Education of youth. It is helpful for young people to realize that personal prospect and the motherland's future are closely related. As long as all people unite as one and struggle together, the goal of national prosperity and rejuvenation will come true. Meanwhile, personal dreams will be finally realized.

Second, the government should deepen reform, realize the rational allocation of resources, and safeguard social fairness and justice.

Internet users believed that the serious injustice and corruption had severely reduced national confidence to achieve the Chinese Dream. To agglutinate the power of the dream, the government must gather consensus further, "break mental shackles and vested interests with great determination, and purse economic reform as the key step to deepen comprehensive reform in all areas." [7]

On the one hand, the government should vigorously improve the reform of income distribution system, and curb the wealth gap within a lawful, reasonable and moderate scope. At the same time, it should take an active response to public's concerns and demands, increase anti-corruption efforts, accelerate the institutional construction, and reshape the image of public servants, and recast the credibility of the government departments.

On the other hand, the government should pay more attention to social fairness, and build a fair platform which really allows people to enjoy fair rights, rules and opportunities. As President Jin-Ping XI said in a speech in the United States, "the Chinese Dream is the dream of the people. It can be achieved when it completely combines with the Chinese people's longing for a better life." [8] With the good institutional norms and social foundations, what the government constructs for the public can firm people's determination, gather their power, and promote the achievement of the dream as soon as possible.

Third, everyone should work hard to promote the achievement of the Chinese Dream.

"As long as there are dreams, chances, and efforts, all the good things can be created." ${ }^{[1](\mathrm{P} 5)}$ A person who just has dreams could not make his dreams come true. "Solid Work, Rejects Empty Talk." "The achievement of the Chinese Dream is inseparable from the efforts of all Chinese people. Only when the masses closely united for the great rejuvenation of the Chinese nation, the Chinese Dream can be realized." [9] As a part of China, the general public should try their best to do their work. This is the only way to realize personal dreams, and promote the realization of the Chinese Dream at the same time.

In short, there are some problems in Chinese cyber citizens' understanding on Chinese Dream at present, but as WWP, the Britain's largest advertising and public relations group, pointed out, "the attraction of the Chinese Dream will surpass the American Dream in the future." ${ }^{[10]}$ We believe that, with the efforts of the government, schools, the media and ordinary people in china, Chinese Dream, the Chinese people's long-cherished wish will come true!

\section{References}

[1] Jin-Ping XI, The Speech at the First Session of the 12th National People's Congress, People's Publishing House. (2013) 3.

[2] Information on http://politics.people.com.cn/n/2013/0118/c1001-20253603.html; http://www.stats.gov.cn/tjsj/zxfb/201401/t20140120_502082.html

[3] Information on http://www.china.com.cn/economic/txt/2005-09/21/content_5975712.htm 
[4] Information on http://www.guancha.cn/politics/2013_12_04_190256.shtml

[5] Ting GONG, and Mu-Luan WU, The Report on Corruption Case from 2000 to 2009 in China. Sociological Studies, 2012(4):204-220.

[6] Ming ZHANG, The Characteristic, Value Orientation and Realization Path of Chinese Dream, Journal of Xinjiang Normal University (Social Sciences), 2013(4):16-22.

[7] Information on http://lianghui.people.com.cn/2014npc/n/2014/0305/c376646-24535026.html

[8] Information on http://news.qq.com/a/20150924/028892.htm

[9] Gui-Qing XIAO, The Fundamental Way, Spiritual Support and Power Sources to Realize Chinese Dream. Ideological \& Theoretical Education, 2013(11):4-10.

[10] Information on http://news.xinhuanet.com/world/2014-03/23/c_119896253.htm 